\title{
FAKTOR-FAKTOR YANG BERHUBUNGAN DENGAN KELUHAN NYERI PUNGGUNG BAWAH (LOW BACK PAIN) PADA NELAYAN DI DESA BATU KARAS KECAMATAN CIJULANG PANGANDARAN
}

\author{
ASSOCIATING FACTORS WITH LOW BACK PAIN IN FISHERMEN IN BATU KARAS, \\ CIJULANG PANGANDARAN
}

\author{
Atthariq Wahab \\ Program Studi Kedokteran, Fakultas Kedokteran dan Kesehatan, Universitas Muhammadiyah Jakarta \\ Korespondensi: Atthariq Wahab. Email: atthariqwahab@yahoo.co.id
}

\begin{abstract}
ABSTRAK
Data hasil penelitian Kementerian Kesehatan pada 2006 mengenai penyakit dan kecelakaan yang terjadi pada nelayan dan penyelam tradisional, menyebutkan bahwa sejumlah nelayan di Pulau Bungin, Nusa Tenggara Barat menderita nyeri persendian (57,5 persen) dan gangguan pendengaran ringan sampai ketulian (11,3 persen). Hasil riset kesehatan penelitian awal pada nelayan di Desa Batukaras menunjukan dari 10 penyakit terbanyak didominasi penyakit-penyakit yang berhubungan dengan nyeri punggung bawah (low back pain). Penelitian ini bertujuan mengeskplorasi faktor-faktor yang berhungan dengan keluhan nyeri punggung bawah (low back pain) pada nelayan di desa batu karas kecamatan cijulang pangandaran menggunakan pendekatan kuantitatif dengan rancangan penelitian cross sectional. Populasi pada penelitian ini adalah Kelompok Nelayan Masyarakat Desa Batu Karas. Pengambilan sampel ini dilakukan berdasarkan nelayan yang hadir pada saat penelitian (accidental sampling) dan bersedia menjadi responden penelitian dengan mengisi dan menandatangani inform consent sebanyak 140 responden. Pengambilan data dilakukan dengan wawancara terstruktur dengan kuesioner. Variabel yang secara statistik memiliki hubungan yang bermakna dengan kejadian keluhan nyeri punggung bawah adalah masa kerja, kebiasaan merokok, dengan nilai p-value <0,005. Kesimpulan penelitian ini adalah masa kerja lebih dari 20 tahun dan kebiasaan merokok berhubungan dengan nyeri punggung bawah.
\end{abstract}

Kata Kunci: Nelayan, Low Back Pain, Masa Kerja, Kebiasaan Merokok

\begin{abstract}
Data from the Ministry of Health's 2006 research on diseases and accidents that occur in fishermen and traditional divers, said that a number of fishermen on Bungin Island, West Nusa Tenggara suffered from joint pain (57.5 percent) and mild to deafness hearing loss (11.3 percent) The results of the initial research health research on fishermen in Batukaras Village showed that the 10 most diseases were dominated by diseases related to low back pain. The aim of this study is to explore causes factor asscociation with low back pain in Batu Karas Village Community Fishermen Group. This study uses a quantitative approach with a cross sectional study design. The population in this study was the Batu Karas Village Community Fishermen Group. This sampling was carried out based on the fishermen presented at the time of the study (accidental sampling) and willing to become research respondents by filling out and signing informed consent as many as 140 respondents. Data retrieval is done by structured interviews with questionnaires. Variables that have a statistically significant relationship with the incidence of complaints of lower back pain are years of work, smoking habits, with a p-value <0.005. The conclusion of this study are the work period of more than 20 years and smoking habits associated with lower back pain.
\end{abstract}

Key words: Fishermen, Low Back Pain, The Work Period, Smoking Habits

How To Cite: Wahab, A. (2019). FAKTOR-FAKTOR YANG BERHUBUNGAN DENGAN KELUHAN NYERI PUNGGUNG BAWAH (LOW BACK PAIN) PADA NELAYAN DI DESA BATU KARAS KECAMATAN CIJULANG PANGANDARAN. Biomedia, 11(1), 35-40. doi:https://doi.org/10.23917/biomedika.v11i1.7599

DOI: https://doi.org/10.23917/biomedika.v11i1.7599

\section{PENDAHULUAN}

Negara Indonesia merupakan salah satu negara di Asia Tenggara yang strategis karena letak geografisnya yang berada di garis khatulistiwa dan berada di antara benua Asia dan
Australia. Indonesia juga berada di antara samudra Pasifik dan samudra Hindia. Indonesia disebut sebagai negara kepulauan karena terdiri dari 17.480 pulau. Panjang garis pantai negara Indonesia adalah 95.181 kilometer dan 
merupakan garis pantai terpanjang urutan keempat di dunia. Sebagai negara kepulauan terbesar dengan luas lautan tiga per empat dari luas daratan. Guru Besar Fakultas Perikanan dan Kelautan IPB, Prof. Rochmin Dahuri mengatakan produksi sektor ekonomi kelautan Indonesia adalah yang paling besar di dunia dengan potensi mencapai 1,2 triliun dolar AS per tahun (Rahmawati, 2014).

Dari jumlah penduduk sekitar 234,2 juta di Indonesia sebanyak 67,87 juta bekerja di sektor informal sebagai nelayan atau sekitar 30\% penduduk Indonesia mempunyai profesi sebagai nelayan, komposisi ini menunjukan bahwa kontribusi nelayan dalam memberikan sumbangan dan memegang peranan penting dalam pembangunan serta merupakan salah satu asset dalam perekonomian Negara (Badan Pusat Statistik, 2011).

Definisi nelayan dalam undang-undang No. 45 tahun 2009 dijelaskan bahwa "nelayan adalah orang yang mata pencahariannya melakukan penangkapan ikan". Di bagian lain disebutkan nelayan adalah suatu kelompok masyarakat yang kehidupannya tergantung langsung pada hasil laut, baik dengan cara melakukan penangkapan ataupun budidaya (DPR Republik Indonesia, 2017). Mereka pada umumnya tinggal di pinggir pantai, sebuah lingkungan pemukiman yang dekat dengan lokasi kegiatan. Para nelayan mempunyai peran yang cukup besar dalam memenuhi ketersediaan protein bagi jutaan penduduk di berbagai pelosok negara Indonesia ini (Direktorat Kesehatan Kerja, 2013).

Namun, disamping peran pentingnya dalam ketersediaan protein dari hasil laut bagi penduduk Indonesia. Nelayan memiliki risiko terkena Penyakit Akibat Kerja (PAK). PAK adalah setiap penyakit yang disebabkan oleh pekerjaan atau lingkungan kerja (Peraturan Menteri Tenaga Kerja dan Transmigrasi No. Per.01/MEN/1981) yang disebabkan oleh sejumlah faktor, sebagian berasal dari tempat kerja, dan penyakit gaya hidup yang disebabkan oleh satu atau beberapa faktor risiko gaya hidup. Selain itu pekerja juga berisiko terkena cedera akibat kecelakaan kerja (Menteri Tenaga Kerja dan Transmigrasi, 1981).

Banyak kasus penyakit akibat kerja dan kecelakaan kerja pada nelayan yang disebabkan oleh perilaku dan lingkungan kerja yang tidak sehat dan tidak aman. Seperti merokok, pola makan yang tidak sehat, stress, faktor fisik terpapar (panas atau dingin, bising dan radiasi), faktor biologi (bakteri, jamur, virus), faktor ergonomi kerja meliputi postur kerja monoton dan tidak nyaman dengan beban yang berat dan berlangsung dalam waktu yang lama. Data hasil penelitian Kementerian Kesehatan pada 2006 mengenai penyakit dan kecelakaan yang terjadi pada nelayan dan penyelam tradisional, menyebutkan bahwa sejumlah nelayan di Pulau Bungin, Nusa Tenggara Barat menderita nyeri persendian (57,5 persen) dan gangguan pendengaran ringan sampai ketulian (11,3 persen). Hasil riset kesehatan pada penelitian awal pada nelayan di Desa Batukaras menunjukan dari 10 penyakit terbanyak didominasi penyakit-penyakit yang berhubungan dengan penyakit otot (Fakultas Kedokteran dan Kesehatan Universitas Muhammadiyah Jakarta, 2016).

Nyeri Punggung Bawah atau Low Back Pain $(L B P)$ adalah suatu keadaan dengan rasa tidak nyaman atau nyeri akut pada daerah ruas lumbalis kelima dan sarkalis (L5-S1) (Pheasant, 1991). Work-Related Low Back Pain adalah rasa nyeri dalam konteks pekerjaan dan secara klinis mungkin disebabkan oleh pekerjaan atau dapat diperburuk oleh aktifitas pekerjaan (Beeck and Hermans, 2000). LBP merupakan kesakitan yang sangat umum. Sekitar dua pertiga dari populasi orang dewasa di Amerika Serikat (AS) menderita LBP pada suatu saat dalam kehidupan mereka (Deyo and Weinstein, 2001).

Faktor pekerjaan merupakan masalah utama pada ergonomi, aktivitas nelayan yang sering melakukan gerakan berulang mengharuskan nelayan melakukan pekerjaan dalam posisi dinamis menyebabkan keluhan pada otot (skeletal). Dari hasil survey awal keluhan musculoskeletal sangat sering dirasakan oleh nelayan, terutama keluhan nyeri punggung bawah.

Penelitian yang mengeksplorasi faktor faktor yang berhubungan dengan keluhan Nyeri Punggung Bawah (Low Back Pain) pada Nelayan di Desa Batu Karas Kecamatan Cijulang Kabupaten Pangandaran belum pernah dilakukan

\section{METODE}

Penelitian ini menggunakan pendekatan kuantitatif dengan rancangan penelitian cross sectional. Penelitian ini dilaksanakan di Desa Batu Karas Kecamatan Cijulang Kabupaten Pangandaran pada bulan Mei tahun 2017. Kegiatan penelitian meliputi survey pendahuluan, 
pengambilan data primer (pengisian kuesioner karakteristik responden serta kebiasaan atau perilaku responden) dan pengambilan data sekunder (profil kesehatan dan wilayah tempat penelitian). Populasi pada penelitian ini adalah Kelompok Nelayan Masyarakat Desa Batu Karas. Pengambilan sampel ini dilakukan berdasarkan nelayan yang hadir pada saat penelitian (accidental sampling) dan bersedia menjadi responden penelitian dengan mengisi dan menandatangani inform consent. Sampel dalam penelitian ini adalah nelayan di dua dusun Desa Batu Karas Kecamatan Cijulang Kabupaten Pangandaran sebanyak 142 orang yang hadir dalam penelitian dan yang bersedia menjadi responden penelitian sebanyak 140 responden, dikarenakan 2 orang nelayan keberatan untuk diambil sampel darah dan urin. Jadi total sampel dalam penelitian ini sebanyak 140 responden.

Pengambilan data dilakukan dengan wawancara terstruktur dengan kuesioner. Uji statistic yang digunakan adalah uji chi square dikarenakan variabel independen dan variabel dependen merupakan data kategorik. Variabel dependen pada penelitian ini adalah keluhan nyeri punggung bawah (low back pain) pada nelayan di Desa Batu Karas Kecamatan Cijulang Kabupaten Pangandaran. Dan variabel independen dalam penelitian ini adalah umur, Indek Massa Tubuh, masa kerja, lama kerja, kebiasaan merokok, dan kebiasaan olahraga pada Nelayan di Desa Batu Karas Kecamatan Cijulang Kabupaten Pangandaran Tahun 2017.

\section{HASIL DAN PEMBAHASAN}

Pada Tabel 1 diketahui bahwa nelayan dengan keluhan nyeri punggung sebesar $36,4 \%$. Sebagian besar IMT nelayan masuk dalam kategori IMT tidak ideal yaitu sebesar $70.0 \%$.
Dari hasil analisis variabel umur, didapatkan ratarata umur responden adalah 47 tahun, median 45 tahun $(95 \%$ CI : 45,46 - 47,64) dengan standard deviasi 6,322 tahun. Umur termuda 25 tahun dan umur tertua 75 tahun. Sedangkan, distribusi responden menurut kelompok umur diketahui bahwa sebagian kecil adalah responden yang berumur $>45$ tahun yaitu $40 \%$ dan sebagian besar responden yang berumur $\leq 45$ tahun yaitu $60 \%$.

Tabel 1. Distribusi Responden Menurut keluhan nyeri punggung bawah

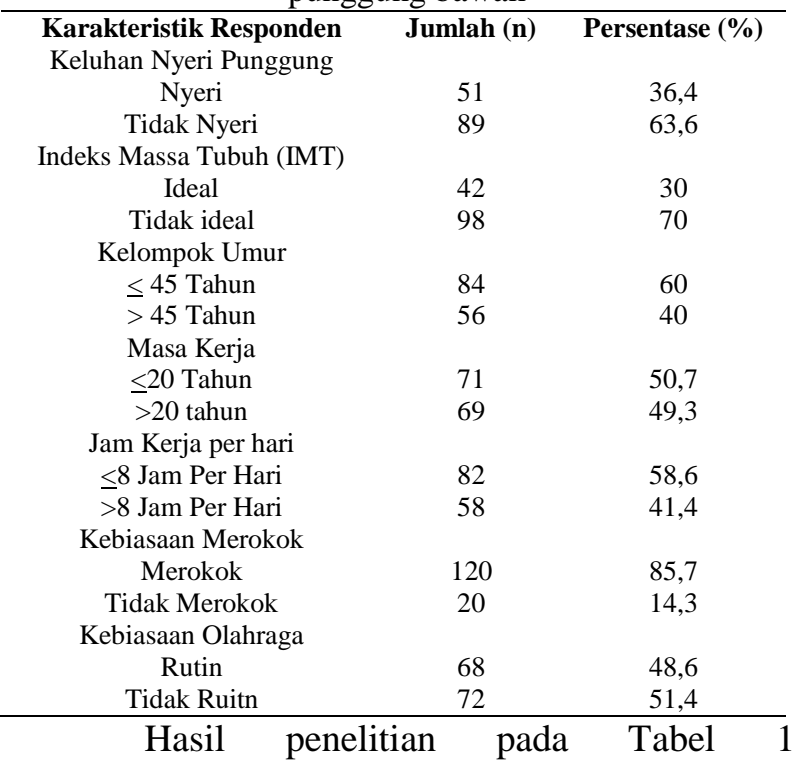

menunjukkan bahwa sebagian besar masa kerja nelayan adalah kurang dari sama dengan 20 tahun sebanyak 50,7\%. Selain itu, sebagian besar jam kerja per hari nelayan kurang dari sama dengan 8 jam per hari sebanyak $58,6 \%$. Nelayan dengan kebiasaan merokok memiliki persentase paling besar yaitu $85,7 \%$. Kebiasaan olahraga pada nelayan responden sebagian besar tidak rutin berolahraga yaitu sebanyak $51,4 \%$.

Tabel 2. Hubungan Karakteristik Responden dengan Keluhan Nyeri Punggung Bawah (Low Back Pain)

\begin{tabular}{|c|c|c|c|c|c|c|c|c|c|}
\hline \multirow{3}{*}{\multicolumn{2}{|c|}{ Karakteristik Responden }} & \multicolumn{4}{|c|}{ Nyeri Punggung Bawah (Low Back Pain) } & \multirow[t]{3}{*}{ p value } & \multirow[t]{3}{*}{ OR } & \multicolumn{2}{|c|}{ 95\% CI } \\
\hline & & \multicolumn{2}{|c|}{ Ya } & \multicolumn{2}{|c|}{ Tidak } & & & \multirow[t]{2}{*}{ Lower } & \multirow[t]{2}{*}{ Upper } \\
\hline & & $\mathbf{n}$ & $\%$ & $\mathbf{n}$ & $\%$ & & & & \\
\hline \multirow{2}{*}{ Umur } & $\leq 45$ Tahun & 27 & 32,1 & 57 & 67,9 & \multirow{2}{*}{0,214} & \multirow{2}{*}{1,583} & \multirow{2}{*}{1,78} & \multirow{2}{*}{3,18} \\
\hline & $>45$ Tahun & 24 & 42,9 & 32 & 57,1 & & & & \\
\hline \multirow{2}{*}{ IMT } & Ideal & 18 & 42,9 & 24 & 57,1 & \multirow[b]{2}{*}{0,199} & \multirow{2}{*}{0,677} & \multirow[b]{2}{*}{0,34} & \multirow{2}{*}{1,40} \\
\hline & Tidak Ideal & 33 & 33,7 & 65 & 66,3 & & & & \\
\hline \multirow{2}{*}{ Masa Kerja } & $\leq 20$ Tahun & 24 & 33,8 & 47 & 66,2 & \multirow{2}{*}{$0,031^{*}$} & \multirow{2}{*}{1,259} & \multirow{2}{*}{1,63} & \multirow{2}{*}{2,50} \\
\hline & $>20$ Tahun & 27 & 39,1 & 42 & 60,9 & & & & \\
\hline Jam Kerja & $\leq 8 \mathrm{Jam}$ & 30 & 36,6 & 52 & 63,4 & \multirow{2}{*}{0,100} & \multirow{2}{*}{0,894} & \multirow{2}{*}{0,48} & \multirow[b]{2}{*}{1,97} \\
\hline Per Hari & $>8 \mathrm{Jam}$ & 21 & 36,2 & 37 & 63,8 & & & & \\
\hline Kebiasaan & Tidak Merokok & 10 & 50 & 10 & 50 & \multirow{2}{*}{$0,021^{*}$} & \multirow{2}{*}{1,927} & \multirow{2}{*}{0,74} & \multirow{2}{*}{5,03} \\
\hline Merokok & Merokok & 41 & 34,2 & 79 & 76,3 & & & & \\
\hline Kebiasaan & Tidak Rutin & 27 & 37,5 & 45 & 62,5 & \multirow{2}{*}{0,861} & \multirow{2}{*}{0,909} & \multirow{2}{*}{0,45} & \multirow{2}{*}{1,81} \\
\hline Olahraga & Rutin & 24 & 35,3 & 44 & 64,7 & & & & \\
\hline
\end{tabular}


Tabel 2 merupakan hasil analisis bivariat mengenai hubungan karakteristik responden dengan keluhan nyeri punggung bawah (low back pain) pada nelayan. Hasil analisis tersebut menunjukkan bahwa umur, IMT, jam kerja per hari dan kebiasaan olahraga tidak berhubungan dengan kejadian nyeri punggung bawah (low back pain) pada nelayan, sedangkan masa kerja dan kebiasaan merokok memiliki hubungan yang signifikan. Hal ini dibuktikan dengan nilai $\mathrm{p}$ value pada umur, IMT, jam kerja per hari dan kebiasaan olahraga lebih dari $0,05(\mathrm{p}=>0,05)$ yaitu 1,583 ; 0,677 dan 0,894. Pada variabel masa kerja, nelayan dengan masa kerja >20 tahun berisiko 1,2 kali lebih besar mengalami nyeri punggung bawah dibanding nelayan dengan masa kerja $<20$ tahun $(\mathrm{OR}=1,259 ; 95 \% \mathrm{CI}=1,63-2,50)$. Nelayan yang memiliki kebiasaan merokok berisiko 1,9 kali lebih besar mengalami nyeri punggung bawah $(\mathrm{OR}=1,927 ; \quad 95 \% \quad \mathrm{CI}=0,74-5,03) \quad$ dibanding nelayan yang tidak merokok.

Hasil penelitian menyatakan bahwa umur tidak berpengaruh terhadap kejadian nyeri punggung bawah (low back pain).

Nyeri punggung bawah pada usia tersebut dimungkinkan karena pada kelompok umur tersebut responden sedang dalam usia produktif sehingga aktivitas yang lebih banyak menyebabkan rasa nyeri pada bagian tubuh yang sering digunakan, salah satunya punggung bawah. Semakin meningkatnya usia seseorang berbanding lurus dengan semakin menurun kepadatan tulang, sehingga mudah mengalami keluhan-keluhan otot skeletal dan menimbulkan nyeri. Kekuatan maksimal otot pada manusia terjadi pada saat usia antara 20-29 tahun, dan pada usia mencapai 60 tahun rata-rata kekuatan otot akan menurun sampai 20\% dan dari faktor lain karena sikap yang tidak ergonomik mengakibatkan terjadinya nyeri punggung bawah (Pheasant, 2003).

Indeks Massa Tubuh pada penelitian ini juga tidak berhubungan dengan nyeri punggung bawah. Berbanding terbalik dengan pernyataan bahwa seseorang yang memiliki indeks masa tubuh abnormal berisiko mengalami keluhan di daerah punggung bawah dua kali lebih tinggi daripada orang dengan indeks masa tubuh normal (Suma'mur, 2009). Hal ini disebabkan tulang belakang akan tertekan ketika berat badan bertambah, sehingga akan mudah mengakibatkan terjadi kerusakan dan bahaya pada stuktur tulang belakang. Bahkan, penelitian lain menyatakan bahwa seseorang yang overweight lebih berisiko 5 kali menderita LBP dibandingkan dengan orang yang memiliki berat badan ideal. Salah satu daerah pada tulang belakang yang paling berisiko akibat efek dari obesitas adalah verterbrae lumbal (Purnamasari et al., 2010).

Hasil penelitian menunjukkan bahwa masa kerja berhubungan dengan nyeri punggung bawah, hal ini dikarenakan nyeri punggung bawah (low back pain) merupakan penyakit yang membutuhkan waktu lama untuk bermanifestasi atau menimbulkan suatu dampak. Sehingga semakin lama seseorang terpajan dengan faktor risiko, semakin besar pula kemungkinan mengalami nyeri punggung bawah (Andini, 2015). Pada penelitian ini, pekerja dengan masa kerja lebih dari 20 tahun berisiko 1,2 kali lebih besar mengalami nyeri punggung bawah. Penelitian lain menyebutkan bahwa keluhan nyeri punggung bawah dapat dialami oleh pekerja yang memiliki masa kerja lebih dari 10 tahun dibandingkan dengan mereka dengan masa kerja kurang dari 5 tahun ataupun 5-10 tahun (Umami et al., 2014).

Variabel jam kerja per hari pada penelitian ini tidak berhubungan dengan kejadian nyeri punggung bawah. Pada penelitian lain, jam kerja per hari atau durasi pajanan terhadap risiko berpengaruh terhadap kejadian low back pain. Selama berkontraksi otot memerlukan oksigen. Risiko fisiologis utama yang dikaitkan dengan gerakan yang sering dan berulang-ulang adalah kelelahan otot. Jika gerakan berulang-ulang dari otot menjadi terlalu cepat sehingga oksigen belum mencapai jaringan maka akan terjadi kelelahan otot (Straker and Duncan, 2000).

Hasil penelitian riskedas 2013 menunjukkan bahwa petani/nelayan/buruh adalah perokok aktif setiap hari yang mempunyai proporsi terbesar $(44,5 \%)$ dibandingkan kelompok pekerjaan lainnya (Badan Penelitian dan Pengembangan Kesehatan Republik Indonesia, 2013). Hubungan yang signifikan antara kebiasaan merokok dengan keluhan otot pinggang, disebabkan nikotin pada rokok dapat menyebabkan berkurangnya aliran darah ke jaringan (Kantana, 2012). Terlebih pada pekerjaan yang memerlukan pengerahan otot sehingga aliran darah yang membawa sari makanan amat diperlukan untuk kepentingan metabolisme pada jaringan. Selain itu, kebiasaan merokok juga dapat menurunkan kapasitas paru-paru, sehingga kemampuan untuk mengkonsumsi oksigen menurun dan sebagai akibatnya tingkat kesegaran tubuh juga menurun (Boshuizen et al., 1993). Penelitian lain melaporkan bahwa hubungan 
antara merokok dengan nyeri pinggang, didapatkan hasil kejadian low back pain lebih banyak pada responden dengan perilaku merokok daripada yang tidak pernah merokok sama sekali (Yuliana, 2011).

Hasil penelitian pada tabel 2 menunjukkan bahwa kebiasaan olahraga tidak berpengaruh dengan kejadian low back pain. Hasil penelitian ini sejalan dengan penelitian lain yang menyatakan bahwa kebiasaan olahraga tidak memiliki hubungan yang signifikan dengan keluhan nyeri punggung bawah (Umami et al., 2014). Kebiasaan olahraga yang dilakukan oleh seseorang akan mempengaruhi kesegaran jasmani tubuhnya. Seseorang yang terbiasa berolahraga akan memiliki kesegaran jasmani yang lebih baik dibandingkan dengan orang yang jarang atau tidak pernah berolahraga (Nurmianto, 2008).

\section{SIMPULAN}

Masa kerja dan kebiasaan merokok merupakan faktor yang mempengaruhi keluhan Nyeri Punggung Bawah (Low Back Pain) pada Nelayan di Desa Batu Karas Kecamatan Cijulang Kabupaten Pangandaran

\section{DAFTAR PUSTAKA}

Andini, F. 2015. Risk factors of low back pain in workers. Journal Majority, 4(1), 12-19.

Badan Penelitian dan Pengembangan Kesehatan Republik Indonesia. 2013. Riset Kesehatan Dasar (RISKESDAS) 2013. Badan Penelitian dan Pengembangan Kesehatan Kementerian Kesehatan RI. https://doi.org/1 Desember 2013

Badan Pusat Statistik. 2011. Statistik Indonesia 2011. Badan Pusat Statistik. Jakarta

Beeck, L. R. Op De, and Hermans, D. V. 2000. Research on work-related low back disorders. Belgium: Luxembourg: Office for Official Publications of the European Communities.

Boshuizen, H., Verbeek, J., and Broersen, J. 1993. Do smokers get more back pain? Amsterdam: The Netherlands: Elsevier.

Deyo, R. A., and Weinstein, J. N. 2001. Low Back Pain. The New England Journal of Medicine, (344), 363-370. https://doi.org/10.1056/NEJM200102013440508

Direktorat Kesehatan Kerja. 2013. Profil Kesehatan Nelayan. Jakarta.

DPR Republik Indonesia. 2017. Undang-Undang Republik Indonesia Nomor 45 Tahun 2009 Tentang Perubahan Atas Undang-Undang Nomor 31 Tahun 2004 Tentang Perikanan, Pub. L. No. 45.

Fakultas Kedokteran dan Kesehatan Universitas Muhammadiyah Jakarta. 2016. Profil Kesehatan Nelayan Desa Batu Karas. Jakarta.

Kantana, T. 2012. Faktor-faktor yang mempengaruhi keluhan low back Pain pada kegiatan mengemudi TIM ekspedisi PT enseval putera megatrading Jakarta Tahun 2010. Uin Syarif Hidayatullah.

Menteri Tenaga Kerja dan Transmigrasi. 1981. Kewajiban Melapor Penyakit Akibat Kerja, Pub. L. No. 1.

Nurmianto, E. 2008. Ergonomi: Konsep Dasar dan Aplikasinya. Surabaya: Guna Widya.

Pheasant, S. 1991. Ergonomics, Work and Health. https://doi.org/10.1007/978-1-349-21671-0

Pheasant, S. 2003. Bodyspace (Anthropometry, Ergnomics and the Design of Work). Taylor \& Francis e-Library.

Purnamasari, H., Gunarso, U., and Rujito, L. 2010. Overweight sebagai Faktor Resiko Low Back Pain Pada Pasien Poli Saraf RSUD Prof. Dr. Margono Soekarjo Purwokerto. Mandala of Health, 4(1), 26-32. 
Rahmawati, L. 2014. Potensi ekonomi kelautan Indonesia 1,2 triliun dolar AS. Antara News Online. Retrieved from https://www.antaranews.com/berita/458852/potensi-ekonomi-kelautanindonesia-12-triliun-dolar-as

Straker, L., and Duncan, P. (2000). Psychophysical and psychological comparison of squat and stoop lifting by young females. Australian Journal of Physiotherapy, 46(1), 27-32. https://doi.org/10.1016/S0004-9514(14)60311-1

Suma'mur. 2009. Higiene Perusahaan dan Kesehatan Kerja (Hiperkes). Jakarta: Sagung Seto.

Umami, A. R., Hartanti, R. I., and Sujoso, A. D. P. 2014. Hubungan antara Karakteristik Responden dan Sikap Kerja Duduk dengan Keluhan Nyeri Punggung Bawah ( Low Back Pain ) Pada Pekerja Batik Tulis ( The Relationship Among Respondent Characteristic and Awkward Posture with Low Back Pain in Batik Workers ). E-Jurnal Pustaka Kesehatan, 2(1), 72-78.

Yuliana. 2011. Low Back Pain. Cermin Dunia Kedokteran, 38(4), 270-273. 